\title{
The Life of Mask Puppet in Jombang: Its Functions and Continuity
}

\author{
Setyo Yanuartuti ${ }^{\bowtie}$ \\ Languages and Arts Faculty, UNESA Surabaya Indonesia
}

Permalink/DOI: http://dx.doi.org/10.15294/komunitas.v6i2.3302

Received : July 2014; Accepted: August 2014; Published: September 2014

\begin{abstract}
Wayang Topeng (Mask Puppet) in Jombang is a folk performance whose presence is needed by the society. Along with the development of the society, it experiences downturn. Currently, various attempts have been made by artists in Jombang to preserve the performance. The study aims to investigate the function and continuity Wayang Topeng functions in today's society. Observation, interviews and literature studies were used to collect the data. The interactive analysis was used as the data analysis model. The result of the study shows that Wayang Topeng in Jombang still has manifest functions such as a vow ritual, a giver of inner experience, a breadwinner, and an entertainment; and latent function which is to form social solidarity. The life of Wayang Topeng after being raised by Purwa has received good response from the people and gained popularity. However, because the regeneration process is not well managed, the existence of this art performance is at the tip of torpor and deterioration. The revival of Wayang Topeng in Jombang is realized soon after a primary school teacher has tried to revitalize it.
\end{abstract}

\begin{abstract}
Abstrak
Wayang Topeng di Jombang merupakan pertunjukan rakyat yang kehadirannya dibutuhkan oleh masyarakat. Seiring dengan perkembangan masyarakat wayang topeng ini mengalami kegoncangan sehingga hilang. Berbagai usaha telah dilakukan oleh seniman-seniman di Jombang hingga saat ini telah muncul kembali. Penelitian ini dilakukan untuk mengetahui fungsi wayang topeng di masyarakat saat ini dan mengetahui kontinuitas kehidupannya. Teknik pengumpulan data menggunakan observasi, wawancara dan studi pustaka, dan analisis interaktif sebagai model analisis datanya. Hasil penelitian menunjukkan bahwa wayang topeng di Jombang masih memiliki fungsi manifes yaitu fungsi ritual nadzar, sebagai pemberi pengalaman batin, sebagai pencari nafkah dan sebagai hiburan; serta fungsi laten yaitu pembentuk solidaritas sosial. Kehidupan wayang topeng setelah dimunculkan oleh Purwa mendapatkan tanggapan yang baik oleh masyarakat sehingga cukup eksis, namun karena proses regenerasi tidak dilakukan menyebabkan kesenian ini mati suri dan kemerosotan. Kebangkitan kembali telah dialami oleh wayang topeng di Jombang setelah ada seseorang guru SD berusaha untuk melakukan revitalisasi.
\end{abstract}

Keywords: function; continuity; life; mask puppet

How to Cite: Yanuartuti, S. 2015. The Life of Mask Puppet in Jombang: Its Functions and Continuity. Jurnal Komunitas, 6(2):222-236. doi:http://dx.doi.org/10.15294/komunitas.v6i2.3302

(C) 2014 Semarang State University. All rights reserved 


\section{INTRODUCTION}

Indonesian society consists of many various ethnicities. This society's ethnic diversity has created various cultures as well. One result of the cultures is the traditional art. Traditional arts have long lived in the midst of public life in accordance with its ethnic groups. Therefore, there are many kinds of traditional arts in Indonesia and each one is unique, peculiar, and different from one region to another. Traditional arts in Indonesia have been born, lived, and grown with the society in which this art exists. One of the arts is the art of mask performance.

The word topeng (mask) comes from the word tup which means "closed", then is added with eng and it becomes tupeng and then it becomes topeng (Ensiklopedi Tari Indonesia, 1986: 96). Each region/area in Indonesia has its own term to say "topeng": tapuk (ancient Javanese language), tapel (Bali, Lombok), kedok (Java-Sunda), toping (Batak Simalungun), hudoq (Dayak), gundalagundala (Karo), etc (Suanda, 2004: 3). The word topeng is not always used to mention a performance that uses a mask. For example, a performance that uses a mask like Wayang Wong in Yogyakarta and Bali is not called topeng while there is a performance that does not to use a mask like in Betawi and Banten, but it is called topeng. It means that the term topeng is sometimes defined narrowly, but can be defined broadly as well.

The term Wayang Topeng (Mask Puppet) in the mask performance in Indonesia refers to the presence of dalang who is a performer and mastermind of the story. The term Wayang Topeng is used in a mask performance in Malang, Klaten, Jombang, Cirebon, etc.

Soedarsono, in his book, Wayang Wong, State Ritual Dance in the Court of Yogyakarta writes that Wayang Topeng in East Java had been known in the 1oth century until the 16th century as a legacy of mask performance that had existed at the time of kingdoms in East Java like Majapahit, called as raket. Later, the book explains that the performance of raket is related to an old Java poetry Nagarakretagama written by $\mathrm{Mpu}$ Prapanca in 1365 A.D which states that the king, Hayam Wuruk, and his father, Kertawardhana, often performed in raket. According to his prediction, raket performance carried Panji story. It can be seen from the term tekes that appears in that old Java poetry which does not mean opera dance drama but is interpreted as a head cover which was worn by dancers in Panji story dance drama (1984: 7-10).

In the area of Malang, Pigeaud (1938: 143) finds that mask performances are found in some places. Mask performance in Malang is very popular. Pigeaud obtains information from the former governor of Malang, Raden Adipati Ario Surioadiningrat, about mask performance in Malang in the late XIX and beginning of the XX centuries. Saritruno (a village chief) was a famous performer who came from Pucangsongo, Tumpang sub district; He was famous for his skill at dancing. The mouth of the mask used by him was closed, which is now at least connected with a rope round the head. Therefore, it does not have any hide/leather piece like in Central Java. Related to that, Henri Supriyanto (1997: 6) also reveals that at that time, in Malang, there was the oldest mask maker named Mbah Reni.

Wayang Topeng in East Java has a number of forms, besides Wayang Topeng Malang, Topeng Dalang Madura; there is also one in Jombang. Mask performances in East Java have been widely researched and written, but not many people know Wayang Topeng in Jombang because there has not been any research which discusses and publishes it in detail. Pigeaud has mentioned that in Jombang area, there is a small mask performance performed around the area from one house to the other and gives a show in short amount of time. In Jombang, on Chinese New Year, there are mask performers going around the area, which is often called amen. Small mask performances in this area presumably consist of only one or some mask dance/s (Pigeaud, 1938: 139). Information on Wayang Topeng in Jombang has already existed but it is not complete. In Jombang, a mask performance called the Wayang Topeng is a mask performance in Jati Duwur, hence, people call it Wayang To- 
peng Jati Duwur. Wayang Topeng Jati Duwur is a mask performance which has achieved success, but it also experienced a downturn even lost. The attempt to preserve this performance is conducted by a primary school teacher named Supriyo. Until this moment on, the performance is finally known by the present society.

The life of Wayang Topeng is interesting to be investigated further. Regarding to such notion, researcher is interested to review it. The writing will focus on the functions and the continuity of Wayang Topeng in the society. The researcher's motivation to discuss this problem is due to a sense of concern about the condition of Wayang Topeng; even though the performance has been raised back, up to this point, it has not really existed in the society. There is a huge expectation from the reseracher that $\mathrm{Wa}$ yang Topeng Jati Duwur which has the characteristic of the art of Jombangan can later be known by general people and get the attention of Governments and art observers, so the life of Wayang Topeng can thrive and have a good continuity in the future.

\section{METHODS}

The research is a field study which has a material object of Wayang Topeng in a village of Kesamben sub-district of Jati Duwur Regency, Jombang, East Java,, while the formal objects are function and continuity. This research was carried out in Jombang. To obtain the data both direct and indirect observation techniques were used. The data was then tracked using interviews and literature studies. The data processing used qualitative analysis techniques with interactive model whose implementation was carried out simultaneously with the process of data collection. To get the valid data, re-checking was done using data triangulation and discussions with colleagues.

\section{RESULTS AND DISCUSSION}

The performance art of Wayang Topeng Jati Duwur is a form of Wayang Topeng performance using the play of Panji story. Wayang Topeng Jati Duwur is also a complex performance in which there are different ele- ments of art. Various elements of the art are blended in one performance. Wayang Topeng performance is regulated by a dalang (puppeteer), while the performers move according to what the dalang is saying. Currently the show is accompanied by gamelan composition Slendro, which is very different from the repertoire of Wayang Topeng Malang that generally uses gamelan composition Pelog Bem. Gamelan musical composition that is used to manage the dynamics of the show is Gamelan musical composition of East Java as well as Gamelan musical composition of Wayang Kulit Ceg-dong - East Java's Wayang Kulit performance, Trowulanan style, the style of dalang Piet Asmara.

In the mask performance of Jati Duwur, the commemoration of the main characters is Panji Inukertapati and Dewi Sekartaji, not Panji Asmara Bangun and Dewi Candra Kirana like in mask performance of Malang. This is due to the majority of the peasant society of Jombang who believe that the meeting of Inukertopati and Dewi Sekartaji is bibit kawit ${ }^{1}$. People of Jati Duwur in particular used to enjoy the performance, although they thought of it as a small performance or 'amen'. These people generally thought that way because it has ujar or nadzar (Supriyo, interview on 4 January 2011).

As folk performance art, Wayang Topeng Jati Duwur's existence is indeed very close with the lives of the people in Jati Duwur village, Kesamben sub-district, Jombang Regency. This is because the art has contributed something to the life of the people. It means that, according to anthropology, Wayang Topeng Jati Duwur is functional for the life of the society. This area includes functionalism based on Biophysics needs and functionalism based on social needs or functionalism in the matter of individual needs and functionalism in the matter of society (Royce, 2007: 81). In general, the whole theory of functionalist has

\footnotetext{
1 Bibit kawit is the origin, an essence that has living spirit and will not die or be destroyed. Therefore, tradition that based on agrarian culture often performs a ceremony wiwit. Wiwit comes from kawitan which means beginning or origin (Beatty, translation Achmad F Saefuddin, 2001: 223)
} 
presumption that all aspects of a society or culture in many ways contribute its function in a society or culture.

The theory of functions always believes that a cultural system of an organism whose parts is not only interconnected but also providing a fair share of maintenance, stability, and the sustainability of the life of the organism. Therefore, all cultural systems have certain requirements to realize its existence (Kaplan and Robert A. Manners, 2002: 77-78). Anthropologist, Radcliffe-Brown (1965: 44) reveals that functionalism is associated with social functions, which is written that: "this one is .... the setting of its continuous presence is that on a certain degree it functionally obeys the principle between the unbound sections of the social system". While Malinowski further emphasizes that something works if it gives functional contributions to individual needs so that the system can live. The contribution of the theory of functions from both anthropologists has been relied upon the next anthropologist in approaching social cultural functions of society.

Robert Merton adds the concept of function by dividing the manifest and latent functions or visible and hidden functions. Manifest function is "the objective consequences that give contribution on adjustment or adaptation to the desired system and realized by participants of the system". Latent function is "the objective consequences of cultural happenings that are not desired or realized" (Kaplan and Robert A Manner, 2007: 79).

The concept of Merton functions is very precise to analyze the function of Wayang Topeng Jati Duwur for the society because Wayang Topeng performance often brings out the latent function that is not realized by people and also artists to happen. Therefore, the discussion of the function of Wayang Topeng will be reviewed based on its manifest and latent functions.

\section{The Manifest Functions}

Wayang Topeng Jati Duwur has had a long life journey together with its society. In asking for Wayang Topeng to perform, the society certainly has the awareness and desire that they expect after watching it. The performers also have desire and expectation which lead them to be willing to practice, act, do the dance, or become dalang and so on. Therefore, Wayang Topeng Jati Duwur has clearly contributed in the preferred adjustment or the manifest function in the concept of Merton. Some of the manifest functions of Wayang Topeng Jati Duwur for the society can be specified as follows:

\section{The means of ritual}

In the history of the life of the society, Javanese before knowing any religions, they had already possessed the concepts of animism and dynamism as their beliefs, and then an influx of Hindu and Buddhist resulted in belief syncretism. The mixture of beliefs between one that used to believe in the power of the universe and another that believe in the presence of the gods and spirits of the ancestors creates new life patterns of the society in times of old kingdoms in Java. Then, the introduction of Islam to Javanese does not mean to remove all Javanese living patterns that had believed in the presence of supernatural powers, deities, and spirits of the ancestors. However, the pattern of life of the society syncretism between believing in invisible objects and also believing in God had been integrated in public life of Jombang in the late nineteenth century and the beginning of twentieth century.

As the evidence that the public of Jombang still believed in the forces of unseen objects, although they had converted into Islam was their belief to the mask in Wayang Topeng Jati Duwur performance. The society at the time often made use of Wayang Topeng Jati Duwur to treat diseases and also to release kaul or ujar or nadzar.

Wayang Topeng Jati Duwur is better known by the society as the mask of nadzar. The term is coined in connection with the society's belief that Wayang Topeng has a 'tuah' (sacred power) that can unburden kaul or nadzar or vows ever spoken when having problems like when their son fell sick, getting sustenance, and so on. The society is certain that the mask in Wayang Topeng 
Jati Duwur performance can unburden when they have nadzar. Supriyo ${ }^{2}$ expressed his concern in his interview that if people of Jati Duwur had kaul or nadzar, they will watch the performance. Based on his opinion, the masks in the performance especially the mask of Klono, Panji and Sekartaji are believed to be sacred so they can detach or release any nadzar or kaul (interview with Supriyo on 4th December 2011).

Society's belief to the mask of Mbah Purwo that has tuah is related to the mask's materials, the manufacturing process, and the form of the mask. The making of this mask is carried out under a banyan tree in the village of Jati Duwur every Friday legi (Javanese date) and is accompanied by fasting ritual for a whole day. The process takes years to complete because the manufacturing process should be accompanied by fasting and meditating (interview with Ngari October 2, 1993, and December 4, 2011 Supriyo). The mask of Wayang Topeng Jati Duwur is made of wood. The mask making process is carried out by means of a ritual associated with the magical aspect. The wood is cut in a triangular form so it creates triangular shaped masks. The tradition of making sacred masks is similar to the one in Bali as expressed by A. Agung Suryahadi in his article entitled "Traditional Balinese Mask" as follows.

Mask that will be used as a means of ceremonies, the final process of the making is performing a ritual such as: prayascita ceremony which is to clean the mask abstractedly. Then, to make the mask to have force of "taksu", ceremony of pasupati is conducted. At the ceremony, the mask makers beg to the God Almighty for His strength to reside in the mask. In order to the mask to have supernatural power, ngerehin ceremony is then held ... This mask is tenget; it means that themask has magical power and is kept in a special room in the temple (Suryahadi).

Ritual activities of the mask has also been performed by Sumarni recently, i.e.

2 Supriyo is someone who has led the group of Wayang Topeng Jati Duwur since 2001. every night of Friday legi, it's always given sandingan. Sandingan or offerings that are provided, according to the local folk and artists' belief, are dedicated to the mask and gong (one of musical instrument in Gamelan repertoire). The spoken mantra is aimed at great-grandpa Purwa (ancestor of Wayang Topeng Jati Duwur) to pray and ask for permission to perform Wayang Topeng so that the performance can run smoothly and safely. Sandingan for the mask and gong, each are placed at different places, and the contents are a little different. Offerings or sandingan for the mask, are considered as a present to the spirit in the mask (the unseen). Sandingan to start the performance of Wayang Topeng Jati Duwur can be seen in the picture below.
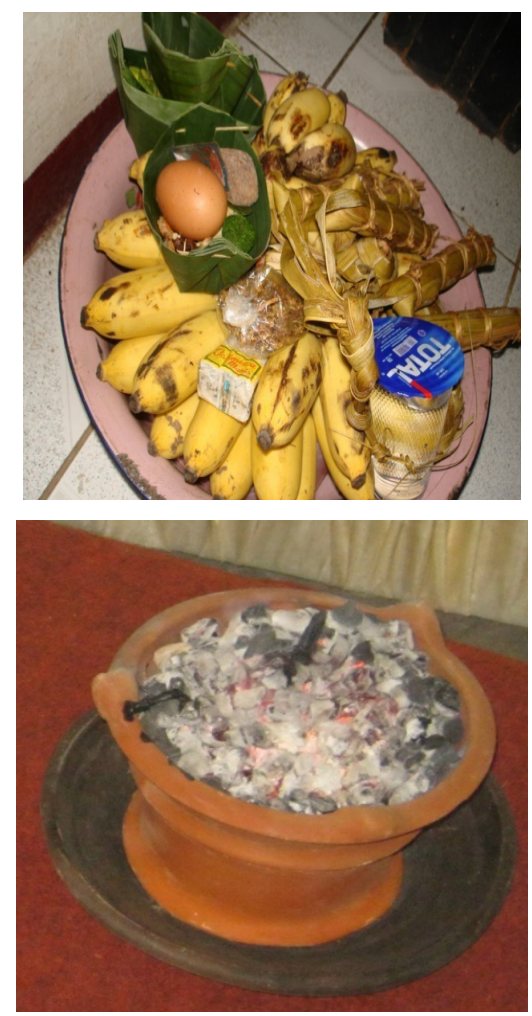

Picture 1. Offerings/sandingan and incense ember for the mask before the performance. (Photo source: Setyo, 2012)

The ceremony to release nadzar is not always the same in various places. Each region or village has its way and tradition because the concern is not solely about the equipment but the ultimate goal is more important. As said by Soedarsono (1976: 3-4) it is not about the requirements or the ce- 
remonial methods that are noteworthy but the spiritual needs of the playgoers that are at stake. After the show, generally, people will feel the calmness in his inner feeling because they have released their promises to the God.

Based on the society's belief, it indicates that Wayang Topeng Jati Duwur at that time and even until recent day still has manifest function. This is because the society is fully aware and willing to hold the performance. The performance will help them to release their kaul or nadzar as their promises to God in order to live achieve a better life. Likewise, if the society prays to the mask for having any diseases, the public knowingly expects the strength of the mask to be able to cure the illness.

\section{The means of inner experience}

Edi Sedyawati (1981: 58) reveals that art has its value as an enjoyment manifested as experience that contains image and process. A work of art is called art if it gives happiness and satisfies the appetites through the experiences. Those experiences can be felt by each individual, depending on each person's readiness.

Wayang Topeng Jati Duwur is a performance art that has high ethical values or philosophical values. The story taken in Wayang Topeng Jati Duwur is the story of Panji, which is a philosophical story that is close to the peasant society. The farmer society has always expected their farm to be fertile so that they can harvest abundant product. Many fertility symbols are used in the performance art. The story of Panji is one of the symbols of fertility. Through the story that always ends with the meeting and the union of Panji Inukertopati and Dewi Sekartaji, symbol of fertility is very well understood by the society of Jati Duwur.

Wayang Topeng Jati Duwur performance has been awaited by the farmer society because it is considered to have been a symbol of fertility. It is expected with such performance, it will grant the hope of the society of bountiful harvest. In addition, through the characters in the story of Pan$\mathrm{ji}$, guidance about the value of the noble- ness of Panji Inukertopati, the patience of Dewi Sekartaji, as well as the power to their struggle when they are forced to separate, but then they disguise themselves with all of the risks, can be taken as a useful value and many more values which can be taken as probing the inner experience.

The performance is expected to able to cultivate a sense of the audience or the young generation to be brought into the atmosphere of the story. Therefore, the audience will feel the inner experience and will be able to change their bad attitudes or behavior, be discerning in dealing with problems, more patience, and so on.

\section{The means of earning wages}

As expressed by Pigeaud (1938: 139), the mask performance in Jombang used to be a small show that performed only a few mask dances. This performance was encountered when it was conducted round the place from one house to another house. This performance is often referred to amen.

We are fully aware that this art was indeed born from the performance used for amen. As amen, the artists' intention doing the performance was clearly to receive wages. After the artists of Wayang Topeng had performed in accordance with the request of the playgoers, artists would be given the wages. It is obvious that the artists of Wayang Topeng fully aware and want to get money from his amen. It means that the purpose of amen is indeed to earn the money to live their life.

At present time, Wayang Topeng Jati Duwur has surely not used for amen, but the show has been conducted in form of complex performance, since there are many elements for art. There are the elements of story, motion, and music or musical composition. The elements of art have been more complete. It can be seen from the number of dancers, the number of music players and so forth, thus performing Wayang Topeng has become a huge mask performance.

Wayang Topeng Jati Duwur performance began to be performed more interestingly so it can be sold and get more feedback, with the hope that it will be able 
to earn more wages as well. Artists are keen to see if their wages from their performance can be used to live their lives. In other words, Wayang Topeng has contribution that possess the objective consistency realized and desired by the performers in order to meet the needs of a living or economic condition of their families.

As acknowledged by Tari, the oldest artist of Wayang Topeng, that: "Yes, quite frankly I can say, I join this mask performance as an artist in order to get wages, so it can be used to support the needs of my family, ning. " (Tari, interview on October 29, 2012).

Supriyo also supports the notion since long time ago. He states that the artists participated in the performance of Wayang Topeng Jati Duwur want to increase the income of their families. Thus, when the performers are asked to do a show without any payment, they will not do it (Supriyo, interview on November 15, 2012).

\section{As Entertainment}

Sumandyo Hadi reveals that some people or artists create beautiful form of art for the purpose of pleasure, either for themselves or others. Most common people associated with art have the core meaning of none other than "pleasure" (Hadi, 2000: 310). It is clear that as a folk art performance, Wayang Topeng Jati Duwur is long awaited by the society, besides the expectation that it can unburden nadzar, it also can provide entertainment or pleasure for the artists, for the society as well as for the playgoers.

The characteristics of folk performance art are presented with dialogue, dance and song; the element of comic always appears; dramatic value is done spontaneously; the performance is at the arena surrounded by audience; and using the local language (Sumardjo, 1992: 19). Wayang Topeng Jati Duwur is created by the artists in the form of a simple performance as the trait of folk performance art is close to the people. Through the simplicity of the form of the show, and the elements of art that are close to the people, Wayang Topeng Jati Duwur is capable of providing entertainment for the people in the middle of the life of rural com- munities who are looking forward to entertainment.

The entertainment function of Wayang Topeng Jati Duwur is increasingly visible at the present time -in the middle of public life that has been easy to get entertainment in any form. The villagers, mainly the older generation, are still loyal and wait for the performance of Wayang Topeng Jati Duwur. Unfortunately, the society seems to be disempowered when they are not able to watch the performance anymore. Due to the increasingly high living demand, Wayang Topeng Jati Duwur has also been abandoned by the artists because they should also struggle to meet the needs of their families. This has been expressed by the society when Wayang Topeng Jati Duwur is being performed.

\section{The Latent Function}

Wayang Topeng Jati Duwur has lived long enough in the midst of Jati Duwur society. There are many kinds of donations that have been given by Wayang Topeng Jati Duwur to the community. Merton reveals that there are many acts of culture in the society with its undesirable objective consequences but nonetheless they occurred. This function is included as a latent function. Art performance often gives different contribution than the expected one. Merton also reveals that the hope dance which aims to be able to send rain does not always succeed in creating rain, but behind that expectation often conjures mysterious function or other function which promotes group solidarity. That function is latent function from a dance in the society (Merton in Kaplan, 2002: 80).

Wayang Topeng Jati Duwur as performance art, which has lived long enough in the society, has also provided the function out of the expected function and is not realized by the artists nor the viewers and the responder community. As found on the hope dance, Wayang Topeng Jati Duwur also has latent function that is forming social solidarity. Wayang Topeng performance is built by artists who originally have family-like relationship or kinship. When doing the performance, the group members of Wayang To- 
peng come just like bringing together family relationship. The meeting at the performance time is going to build and promote group solidarity. As revealed by Supriyo - the coordinator of the current performances, that one of his motivations to reawaken Wayang Topeng at this moment when it is experiencing a slump is because Wayang Topeng is one powerful means to gather citizens of Jati Duwur Village. Officials usually come to where each performance takes place, as well as the people from various villages. Indeed, the purpose of going to the performance is simply watching Wayang Topeng, but in this incidental meeting, officials use it to convey things that build the solidarity outside the show (Supriyo, interview on 5 November 2012).

In addition, when the performance takes place, the people come, meet, and talk to each other and it is possible that there are some deals; those are not planned. Such possible interactions indicate that Wayang Topeng Jati Duwur has contributed in building the social solidarity.

\section{The Continuity of Wayang Topeng}

Performance art as a cultural product of society exists because it is needed by the people. Culture and society is a unity that cannot be separated. Similarly, it happens to the performance art and the society. In its life, performance art depends on its people, how the society makes use of it and how people preserve it. The society always changes; time always changes; so performance art will also change. If the performance art is unwilling to change, gradually, it will be abandoned by the society.

The existence and the continuity of performance art have always been associated with its functions and changes. This can be interpreted that in order to investigate the life and the existence of a performance art, people must connect it with its functions and changes in the society. Kaplan and Robert A Manner (2002: 94) reveals that to search the historical chronology, the process of classification, categorization, and demonstrating the relationship between the types of events must be used. In this case the functional perspective and the perspective of evolution should be combined with a historical perspective.

Wayang Topeng Jati Duwur is one of the performance art that has been living in the society of Jati Duwur Village, Kesamben Sub-district, Jombang Regency. The only form of Wayang Topeng in Jombang is Wayang Topeng Jati Duwur. The people of Jati Duwur Village that mainly work as farmers used to be very certain that this Wayang Topeng Jati Duwur is able to provide inner peace and security in the society life. But when the society develops their belief and also pattern of their life, it will affect the life of Wayang Topeng. Thus, to analyze the life and the continuity or sustainability of Wayang Topeng Jati Duwur, in this case, it will be divided correspond to its functions and changes.

\section{The Origin of Wayang Topeng}

To trace the origin of performance art, Wayang Topeng Jati Duwur existence historically is not easy, because until this study was made, there had not been any data that could be found. If it is investigated based on the play or theme of the story that is performed that is Panji story, then it can be presumed that Wayang Topeng Jati Duwur is a legacy of Majapahit era. As expressed by Sal Murgiyanto and Munardi that at the time of Majapahit, there had been a very popular mask performance and the play of Panji story was very popular (Murdiyanto and Munardi, 1979/1980: 12). Soedarsono also explains that there can be possibility that it is indeed a legacy of Majapahit Kingdom, i.e. from the mask performance called raket that used Panji story.

To know the existence and the continuity of Wayang Topeng Jati Duwur, it can be divided over the category of dalang. This dalang category is selected to divide the functions and its evolution since dalang is the main player in Wayang Topeng, besides $d a-$ lang is the heir of Wayang Topeng.

Soenarto Timur in his writing entitled "Topeng Dhalang di Jawa Timur" writes that in Madura, people call the performance as topeng dalang, whereas in Situbondo 
is more popular with the name of topeng dalang kerte (East, 1979/1980: 1). The performance of Topeng Dalang in Madura uses Mahabarata as the story and Madura as the language. In accordance with the performance in Mojokerto and Jombang, Pigeaud explains that in those areas, there is a small mask performance performed around from house to house and gives a bit of performance. In Jombang on Chinese New Year, there are mask performers going around which is often called 'amen'. Small mask performance in this area presumably consists of only one or some mask dance/s (Pigeaud, 1938: 139).

Based on some writings about the existence of mask performance in East Java, it can be concluded that there are 2 things associated with Wayang Topeng Jati Duwur which serves as a proof about masks of the characters in Panji story created by Sunan Kalijaga and the presence of raket at the time of Majapahit Kingdom that also used Panji story. The relation between Wayang Topeng Jati Duwur and those findings is that Wayang Topeng Jati Duwur uses Panji story until now for the performance. It means that Panji story used in Wayang Topeng Jati Duwur is actually the heritage of Sunan Kalijaga and also the Kingdom of Majapahit.

If we see the form of the performance, the writings of the experts suggest that there are two kinds of performances; small performance and large performance. Small mask performance is what we call 'amen' that lived among the people, while the large mask performance is a complete mask performance that had been living among the kingdoms or got the attention of the Government such as Duke or Panembahan like in Majapahit, then descended into the areas in Malang and Madura. As such, the existence of the form of Wayang Topeng Jati Duwur was originally a small mask performance that was once used by artists as the art of 'amen'. It also refers to what Sumarni said as the only heir of Wayang Topeng Duwur Teak. In her opinion, Wayang Topeng Jati Duwur is the legacy of her great-grandfather named Purwo. At the first time, Wayang Topeng was brought to Jati Duwur by Purwo from Driyorejo Gre- sik - a region in Gresik Regency bounded by Mojokerto Regency. Sumarni still remembered, when she was a kid, the mask was used to 'amen' around by her grandfather and her parents (Sumarni, interview 4 February 2011).

In accordance with the origin of Wayang Topeng Jati Duwur, there was once statement expressed by Haryati in his research in 1993 that based on spoken data grown in the village, it generally informs that the existence of Wayang Topeng in Jati Duwur village is inseparable from the life of a person known as Purwo. Purwo was touted as a pioneer in Wayang Topeng in Jati Duwur, Jombang. Initially, Purwo had two masks namely Klono and Panji. Both masks were brought by Purwo from Legundi, Mojokerto, which were his parents' inheritance. Because both masks were inheritance from his parents as heirlooms, so wherever Purwo went, they would always be taken, unexceptionally when Purwo got married to a girl from Jati Duwur village (Haryati, 1993: 30).

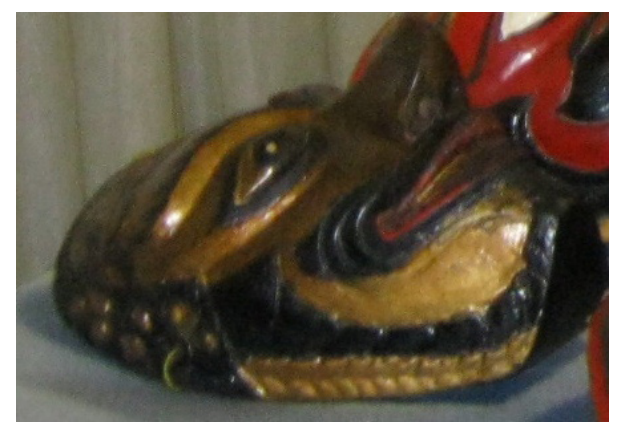

Picture 2. the form of Klana mask considered to have tuah so it can cure any illness (photo source: Setyo, 2012)

Agus as the chairman of mask developer in Jati Duwur who made the replica of the mask in 2011, revealed that from the wood used to make the mask, the age of the oldest mask, Klana mask, considered as a sacred item by its successor, is more than 100 years old (Agus, interview 4 February 2011).

Based on some opinions and evidences that currently exist, the author tentatively suspects that Wayang Topeng Jati Duwur is the heritage of Majapahit Kingdom because it uses Panji as the story. This art was revived 
by the people in form of a small performance which had function as 'amen'. It was brought by an artist named Purwo to the village of Jati Duwur and it has been identified to be more that 100 years old. It can be seen from the wood used in the oldest mask.

\section{The Development of Wayang Topeng}

In the life cycle, there will be events of being born and growth. Growth is the process of becoming or being big, many or widespread. Two major growth principles are (1) the growth takes place from the simple to the complex and (2) from the rough and the global (gross bodily movements) to the subtle and specific but coordinated (finely coordinated movements).

The development of Wayang Topeng Jati Duwur can be seen after Wayang Topeng is in Jati Duwur Village. Currently, there are 33 pieces of masks. Those masks are made by Purwo to add his mask collection and the ones that he possesses. Several years after Purwo lived in Jati Duwur, he wanted to add his collection with some more masks, and then he made some masks himself. The masks have various forms of characters including princess, bapang, priests, warriors and so on. Perhaps Purwo has the expertise of sculpture. The mask making process was carried out under a banyan tree in the village every Friday legi, accompanied by fasting for a whole day. The masks made are 31 pieces, so overall there are 33 pieces of mask.

Based on Supriyo's opinion, Purwo's effort after having 33 pieces of mask was to purchase a set of gamelan from the village of Karang Belah, Sumobito. For the starting point, Purwo invited some of the families living in Jati Duwur to be trained to dance while playing with the mask, as well as the gamelan musicians. Purwo did the coaching himself, as well as acting as dalang. Since then, Purwo and his family had played mask, which was carried out in front of his own house. The group then went around ngamen. That was when people asked them to perform as they had nadzar. After that, there had been people asking to be $\mathrm{cu}^{-}$ red from diseases. When the desires of the people were fulfilled after they watched the performance, it gave the people the belief that Klana mask that Purwo owned had tuah. Since then, people often watched and asked for the performance (Supriyo, interview 5 December 2013).

It is unknown what year and how Purwo died. The thing which can be tracked is that after Purwo had died, the manager of the organization (group) and position of $d a-$ lang were held by the descendants of Purwo. The official of Wayang Topeng passed down from generation to generation. Myth that has grown in the society of Jati Duwur is that the heir of the inheritance must be the person who still has blood descendant of Purwo. Then, the entire things related to the performance from the mask to the other supporting equipment must be placed in Purwo's home. And indeed, the one who becomes dalang must be the heir or descendant of Purwo.

Wayang Topeng has been made more interestingly, it is not uncommon for Wayang Topeng to perform in the form of big mask performance, without going around, but directly perform based on the order. It can be used not only for nadzar but also for entertainment in a marriage or circumcision ceremony.

Since 1990 Wayang Topeng has been managed by a headmaster of SD Jati Duwur named Madekar Hariyanto. Madekar Hariyanto is a leader who is not a direct descendant of Purwo's family, but he was believed by the heir of Purwo who had ever been his adopted father. Madekar has been appointed as a chief and a director since Asim became dalang until Samid took over. At this time, Wayang Topeng performance had been able to perform more complex even though not all elements of art have their aesthetic thought. The society makes use of this art just like before, as a ritual nadzar, and certainly to heal diseases, and also for entertainment. Now, it is not performed around the neighborhood anymore, but the society has to order first if they want to watch the performance.

The play of the story presented in Wayang Topeng now is still Panji story. It can also be seen from the form and the character 
of the masks. The storyline has been arranged like a performance of Wayang Kulit of East Java.

The storyline is formed due to the scenes as follows.

- Jejer Sepisan: Sabrang Kingdom scene

- Grebeg Sabrang/Bodholan

- Bambangan scene/ Warrior of Java scene

- The Failure of the War

- Jejer Kapindho: Padeokan/Pertapan scene

- Jejer Ketelu: The Kingdom of Java scene

- Brubuh War

The venue of the performance is an open space field which can be the house yard of the person who ordered it. Regardless of the stage or elevation, it just needs sesek (a kind of mat made of bamboo), then the top of it is covered by mats. The numbers of the required sesek are approximately 5 pieces, while the mats can be about 4 sheets. When the show was performed during the day, a temporary building must be built at the home yard which has four bamboo poles, roofed by sesek or tarps, called 'terop'. The building is meant to protect the players and pengrawit from the sun or rain. There is no special requirement for the size, but it's adaptable based on the site. For example when the author held the observation, terop was $7 \times 8$ metres, and this was only enough for dancers while pengrawit was on the terrace of the house.

\section{The Deterioration of Wayang Topeng}

Shortly after Wayang Topeng had become a more complex mask performance, it could not keep up. Very unfortunate that in the early 1994s, the players had started to reach old age (about $56-70$ years old), this was because there wasn't any regeneration in the of dalang Darja. The time led to the beginning of a deterioration of the Wayang Topeng existence. It is estimated that Wayang Topeng deterioration was caused by dalang. Since that year, the role of dalang had been held by Samid. As the last line of dalang, Samid Purwo was reputed by people as $d a-$ lang who lacked in strength both in sound quality as well as in the creativity of storytelling, so it increasingly became less attractive
(Supriyo, interview 5 December 2013).

Besides that, regeneration factor also influenced the deterioration of this performance. It was really difficult to do regeneration and look for the replacement of dalang (Sulastri, interview, November 10, 2013), so that in the following years this group never did any show (didn't get any order).

The other deterioration factor outside the internal Wayang Topeng was social factor of people who were more interested in today's entertainments, while there was nobody in the society that wanted to release nadzar with Wayang Topeng. The belief of the masks' power was replaced by strong belief of religious guidance. Some factors mentioned above had really caused Wayang Topeng Jati Duwur to not have any performances until 2000.

\section{The Revival of Wayang Topeng}

This period is the beginning of the revival. In 2001s, in Jati Duwur, there was a person who strove to revive Wayang Topeng Jati Duwur. He is a teacher of Islamic religion in the primary school of Sidokaton, Kudu Subdistrict, Jombang Regency, named Supriyo and commonly called Priyo. When he was a kid, Supriyo was an admirer of Wayang Topeng. Knowing the bad condition of Wayang Topeng, Supriyo wished to revive the glorious performances of Wayang Topeng. However, Supriyo was powerless because he did not have the ability and experience in the artistic activity of Wayang Topeng.

His intention to revive the art seemed to be beyond his ability, so he had to work together with som artists from the outside the village but still in Jombang area. At that time, there were artists who were also incidentally interested in the work done by Supriyo; they are Hartono (dance artist) and Anom Antono (a young dalang with Central Java style). With the help of Hartono and Anom, what Supriyo tried to do was to regenerate the performers by recruiting young boys in the village of Jatiduwur. Hartono and Anom, together with the members of the old artists of Wayang Topeng Jati Duwur that were still left acted as a resource person and coach who did a reconstruction (Suhar- 
tono, interview April 29, 2014). They did a good job. In 2001, Supriyo succeeded to perform 'gebyakan' which took place in front of the heir's house, Sumarni (descendant of Purwo).

The form of Wayang Topeng Jati Duwur now has been reconstructed in terms of repertoire and the clothes. In the attempt and process of the next reconstruction of Wayang Topeng Jati Duwur that had been done for 5 years, it got attention from other artists and Culture section of Department of Tourism, Jombang Regency. Finally, on 16 September 2006, the group successfully performed gebyakan again at Supriyo's home yard with the story of "Patih Kudanarawangsa”. Heru Cahyono, a young man from Jombang who graduated from ISI Yogyakarta majoring in Art of Pedhalangan became dalang.

As a form of his concern, Nasrullillah who served as the head of Culture section of Department of Tourism at that time, brought the group to Jakarta to do a staged performance at East Java Platform, Taman Mini Indonesia Indah. From then on, the show had turned into a show that is not bound by the previous function. That means that when they were asked to perform at the event such as performance in Taman Mini Indonesia Indah, Taman Budaya, and the other places, the function was no longer as means of nadzar ritual, but purely for the purpose of show that would be appreciated by society outside of Jombang. Thus, the form of the show had been packed to have shorter time, and could be carried out at night on a performance stage. Since then, Wayang Topeng Jati Duwur had begun to be known by people in Jombang and the surrounding areas.

The revival of Wayang Topeng was not really smooth. After they were asked several times to hold a show outside the area of Jombang, there was feeling of turmoil among members of the group. There was misunderstanding occurred between Supriyo as the developer who was as well a leader, with the heir and the performers. It was acknowledged by Supriyo that there was misunderstanding related to the payment which was less clear. The performers were not satisfied with the payment distributed, while according to Supriyo, it had been managed and distributed in accordance with the portions. Since then, the group had been sulky and did not want to perform ${ }^{3}$. Therefore, Wayang Topeng Jati Duwur had gone back to decrease. They had not had any performance until 2010.

Supriyo did not stay silent. In 2011, problems in the village could be solved. Business had been grown back again by Supriyo along with Heru Cahyono - Dalang Wayang Kulit Trowulanan style - and Dian Sukarno - Dance Artist. This effort received good response from Arts Council of Jombang which eventually supported the revitalization. The revitalization began by making replica of the masks.

All replicas of the masks had been successfully created initiated by the Arts Council, chaired by Agus, and had been carried out by a sculptor from Ploso named Triman. Triman had made a replica mask just like the oldest mask owned by the heir of Wayang Topeng Jati Duwur. The replica making event was entitled "Revitalizing Mask of Jati Duwur 2011". The result of this event was 40 pieces of replicas but they were still not dyed so these masks could not be used for the show. Together with the launch of the result of the event, performance and problems' clearance of the group were held on January 25, 2011 at the Hall of Jombang Regency.

As an expression of gratitude for the revival of Wayang Topeng, the group held a mask performance at the house of the sole heir to the mask (Sumarni) 4th December 2011. This show took a story of Patah Kudanarawangsa. However, the emergence of Wayang Topeng has always been related to the requests from the Tourism Departement and the Arts Council as well as the good intention of the heir. Therefore, the intensity of the performances has not been stable; it means that it depends on the request of the Department.

Not so long ago, it was 29 September 2012 Supriyo along with his group members

3 Supriyo, wawancara tanggal 25 Nopember 2011. 
requested by the Department of Tourism and Culture of East Java, to perform in the event at Mpu Tantular Museum, Sidoarjo. The show was held in the courtyard of the museum with a mat-layered stage and fitted with a background of plain white fabric. This performance demonstrated the story Patah Kudanarawangsa. The selection of the story according to Heru Cahyono - dalang who had participated in rebuilding Wayang Topeng Jati Duwur - was because the story that had been successfully performed was this story. Heru as dalang from outside of this group had not yet dared to bring another story.

The attempt to revive Wayang Topeng was still not fully realized by all group members. Thus, misunderstanding was always repeated in the body of this group. As it was not long ago, on 20 December 2012 Wayang Topeng Jati Duwur was asked to perform a stage in the festival of Kalijaring in Jombang, but it could not be held because the performers asked for the same payment as when they got tanggapan. Meanwhile, the Department of Tourism could not give the expected payment so the performers did not want to perform. As a result, the Department of Tourism held a part of performance of Wayang Topeng Jati Duwur but instead of fulfilling the artists or the group's wish, they asked one of the dance classes in Jombang to perform. And it did seem to raise new problems in the life of Wayang Topeng Jati Duwur.

Based on events that have been experienced and lived in the life of Wayang Topeng Jati Duwur, it is clear that the life and the deterioration factors of Wayang Topeng Jati Duwur are caused by several factors; the main factors are the artists or the performers, its supporters, and the art itself. Factors from the outside such as the Government and the social condition of the society also have a role in public life. Therefore, in this current condition, it requires the attention of the Government and also those who sincerely wish to develop Wayang Topeng Jati Duwur without any other intentions.

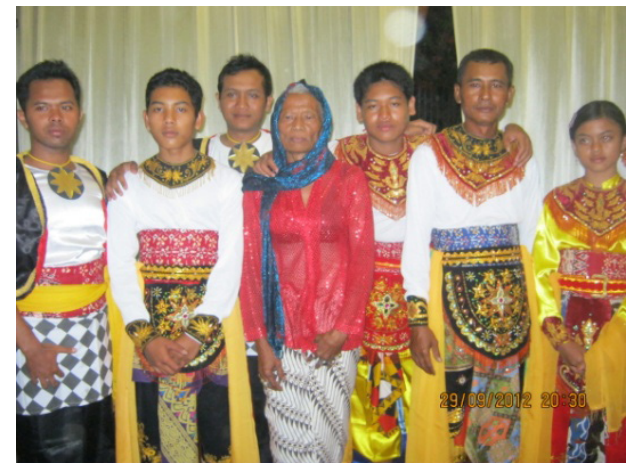

Picture 3. The recent performers taught by $\mathrm{Su}-$ priyo (photo source: Setyo, 2012)

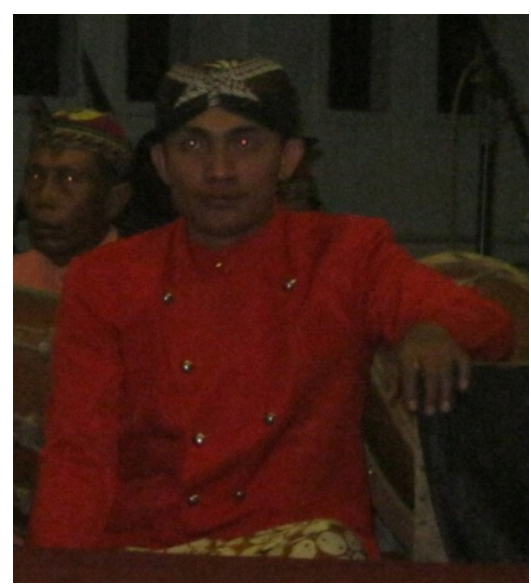

Picture 4. Dalang, Heru Cahyono in the performance at Mpu Tantular Museum (photo source: Setyo, 2012)

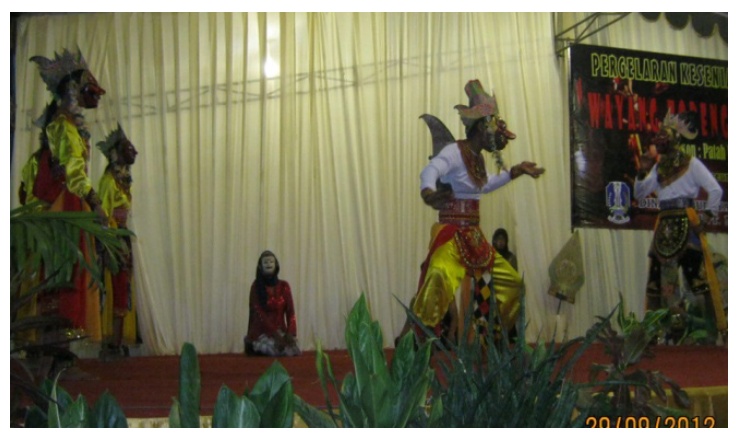

Picture 5. Wayang Topeng Jati Duwur performance held at Mpu Tantular Museum

Surabaya September 29th 2012; Sabrang Kingdom scene

(photo source: Setyo, 2012)

\section{CONCLUSION}

Wayang Topeng Jati Duwur is a folk performance art which has its philosophical value which is used by the society as a guide in their daily life. It has contributed a lot of things to the society which consists of manifest and latent functions since its appearan- 
ce in the village of Jati Duwur. On the basis of objective consequence that has been desired and realized by the artists and society, Wayang Topeng has been functioning as a mean of ritual nadzar, as a mean to probe the inner experience, and as a mean to earn a living. Behind its manifest function, Wayang Topeng also has other contribution as a mean of developing a sense of solidarity in the society.

The life and the continuity of Wayang Topeng Jati Duwur were very tortuous and experienced ups and downs of life brought by Purwo, then passed down to his descendants and eventually the group is led by people outside the descendants, until now it's still not stable. The life and the continuity of Wayang Topeng have been influenced by several factors. The main factors are the artists or the performers, its supporters, and the evolution of art itself. Other factors that affect its life are the Government and the society as well as the observers of the arts.

\section{ACKNOWLEDGEMENT}

A big gratitude goes to the Ditlitabmas Dikti who has provided research funding for the arts sector in the fiscal year of 2013/1014. The gratitude are also addressed to the Rector of the State University of Surabaya, Dean of the Faculty of Languages and Arts that have approved the proposed research, as well as to the Chairman of the Major of Drama, Dance, and Music, Faculty of Languages and Arts, UNESA that has given the writer facility support during the research. In addition, the researcher gives her gratitude to Supriyo as the resource person, Tri Sulastri as Chairman of Wayang Topeng group who has given the writer information and opened the opportunity to do observation.

\section{REFERENCES}

Brandon, J.R. 1989. Seni Pertunjukan di Asia Tenggara. Terj. R.M. Soedarsono. Yogyakarta: ISI.

Darsono. 2007. Budaya Nusantara. Bandung: Rekayasa Sains.

Darsono. 2007. Kritik Seni. Bandung: Rekayasa Sains.
Hadi, S. 2005. Sosiologi Tari. Yogyakarta: Pustaka.

Haryati. 1994. "Wayang Topeng Jati Duwur di Desa Jati Duwur Kecamatan Kesamben Kabupaten Jombang (Studi tentang bentuk dan makna pertunjukan)". Skripsi. IKIP Surabaya.

Herbert, R. 200o. Seni: Arti dan Problematikanya. Terj. Soedarso SP. Yogyakarta: Duta Wacana University Press.

Holt, C. 200o. Melacak Jejak Perkembangan Seni di Indonesia. Alih bahasa Soedarsono. Bandung: Arti Line.

Kaelan. 2012. Metode Penelitian Kualitatif Interdisipliner: Bidang Sosial, Budaya, Filsafat, Seni, Agama, dan Humaniora. Yogyakarta: Paradigma.

Kaplan, D. and Robert A. M. 2002. Teori Budaya. Yogyakarta:Pustaka Pelajar.

Kayam, U. 1981. Seni Tradisi Masyarakat. Jakarta: PT. Sinar Harapan.

Kayam, U. 2001. Kelir Tanpa Batas. Yogyakarta: Gama Media.

Koentjaraningrat. 2010. Sejarah Teori Antropologi I. Jakarta: UI Press.

Koentjaraningrat. 2010. Sejarah Teori Antropologi II. Jakarta: UI Press.

Kuntowidjojo. 1987. Budaya dan Masyarakat. Yogyakarta: Tiara Wacana.

Langer, S.K. 2006. Problematika Seni. Terj. FX. Widaryanto. Bandung: Sunan Ambu Press dan STSI Bandung Press.

Marinis, M.D. 1993. The Semiotics of Performance. Terj. Aine O'Healy. Bloomington dan Indianapolis: Indoana University Press.

Moleong, L. J. 1988. Metode Penelitian Kualitatif. Bandung: PT. Remaja Rosda Karya.

Murgiyanto, S. 1982/1983. Pertunjukan Topeng di Jawa: Analisis Kebudayaan. Depatremen P dan K tahun III no 2.

Murgiyanto, S., et. All (ed.). 2003. Mencermati Seni Pertunjukan I: Perspektif Kebudayaan, Ritual, Hukum.Surakarta: Program Pascasarjana STSI Surakarta.

Pigeaud, Th. G. 1938. Javaanse Volksvertoningen. Batavia: Volkslectuur.

Raffles, T.S. 1917. The History of Java. Kuala Lumpur: Oxford University Press.

Ratna, N.K. 2010. Metodologi Penelitian: Kajian Budaya dan Ilmu Sosial Humaniora Pada Umumnya. Yogyakarta: Pustaka Pelajar.

Ritzer, G. 2003. The Posmodern Social Theory. Juxtapose research and Publication Study Club.

Royce, A.P. 2007. Antropologi Tari. Terj. F.X. Widaryanto. Bandung: Sunan Ambu Press STSI Bandung.

Rustopo, ed. 2012. Seni Pewayangan Kita: Dulu Kini dan Esok. Surakarta: ISI Press Solo,

Rustopo. 2008. Krisis Kritik: Seperempat Abad Pasca Gendon Humardani. Surakarta: ISI Press Surakarta.

Soedarsono, R.M. 1984. Wayang Wong: Drama Tari Ritual Kenegaraan di Keraton Yogyakarta. (Yogyakarta: Gajah Mada University Press. Hal. 7-10. 
Soedarsono and Tati N. 2011. Dramatari di Indonesia, Kontinuitas dan Perubahan. Yogyakarta: Gajah Mada University.

Soelarto, B. t.th. Topeng Madura (Topong). Jakarta: Proyek Pengembangan Media Kebudayaan.

Soetarno. 2004. Wayang Kulit: Perubahan Makna Ritual dan Hiburan. Surakarta: STSI Press.

Soetarno. 2005. Pertunjukan Wayang dan Makna Simbolis. Surakarta: STSI Solo Press.

Soetarno. 2011. Teater Nusantara. Solo: ISI Surakarta Press.

Soetrisno. R. 1981/1982. Topeng Dalang Madura. Surabaya: Kanwil Dep P dan K Propinsi Jawa Timur. Spradley, J.P. 2007. Metode Etnografi. Yogyakarta: Tiara Wacana.

Suanda, E. 2004.Topeng, Jakarta: LPSN.

Supriyanto, Henry dan M. Soleh A.P. 1997. Drama Tari
Wayang Topeng Malang. Malang: Padepokan Seni Mangun Dharma.

Sutrisno, M. and Hendar P. 2005. Teori-teori Kebudayaan. Yogyakarta: Kanisius.

Timur, S. 1979/1980.Topeng Dhalang di Jawa Timur. Jakarta: Proyek Sasana Budaya Dirjen Bud Dep Dik Nas.

Yanuartuti, S. 200o. "Studi Komparasi Pertunjukan Sandur Manduro di Jombang dan Sandur Nggondang di Nganjuk". Laporan penelitian. $\mathrm{DP}_{3} \mathrm{M}$ (Peneliti Muda).

Yanuartuti, S. 2002. "Perubahan Pertunjukan Topong Dheleng Rukun Perawas Dalam Kehidupan Masyarakat di Sumenep Madura". Tesis. Program Pascasarjana Universitas Udayana Denpasar. 